\title{
Performance Evaluation of Solar Assisted Heat Pump Water Heating System
}

\author{
Kokila. R.N ${ }^{1}$, Rajakumar. $S^{2}$ \\ ${ }^{1}$ P.G. Student, Department of Mechanical Engineering, Regional Centre, Anna University, Tirunelveli \\ Region,Tirunelveli-07. \\ ${ }^{2}$ Assistant Professor, Department of Mechanical Engineering, Regional Centre, Anna University Tirunelveli \\ Region, Tirunelveli-07.
}

\begin{abstract}
The application of solar thermal energy in water heating system has received more attention in recent years. The solar water heaters is used both in domestic and industrial use. The variation of solar intensity and atmospheric condition is key issue in determining the performance of solar water heater. The conventional thermosyphon solar water heaters fail to provide hot water supply round the clock in low temperature regions. The use heat pump with solar water heating system provides better water management. The COP of heat pump increases with increase in solar intensity and is energy efficient compared to conventional solar water heaters with electric or gas boosters as auxiliary heat source.

The main objective of this paper is to compare the performance of heat pump assisted solar water heater to conventional solar water heating system for low ambient temperature application. The theoretical analysis of solar water heater with heat pump integration is presented which shows that the collector efficiency and output water temperature can be increased compared to conventional solar water heaters under same solar intensity and ambient condition.
\end{abstract}

\section{Keywords: Solar energy, Heat pump, $\mathrm{CO}_{2}$ refrigerant, Water heater}

\section{DIRECT EXPANSION SOLAR ASSISTED HEAT PUMP (DX-SAHP)}

In direct system solar collector serves as the evaporator of heat pump and refrigerant is circulated through the solar collector. DX-SAHP systems use the solar collector as one potential evaporator for the heat pump. Therefore the refrigerant is passed through a throttling valve just before entering the collector in order to drop its pressure to allow it to evaporate when it collects the solar energy. The refrigerant leaves the collector as a vapor and passes through the compressor causing it to become superheat vapor. This high temperature and pressure vapor then flows through the condenser heat exchanger where it transfers energy into the domestic water tank. The solar panel is usually only one or more sources utilized by the system as evaporator. An air source heat exchanger may also be used when sufficient solar energy is not available.

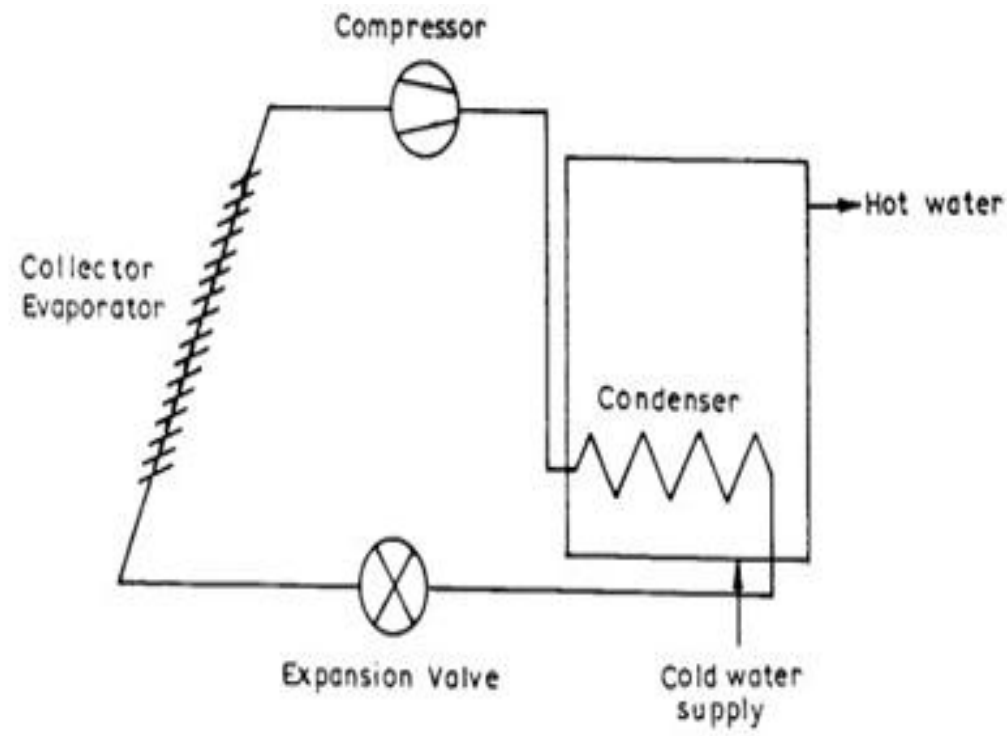

Fig 1.DX-SAHP water heating system 


\begin{tabular}{|c|c|c|c|c|c|}
\hline \multicolumn{3}{|c|}{ NOMENCLATURE } & \multirow{2}{*}{$\begin{array}{l}\mathrm{n} \\
\text { Pred }\end{array}$} & \multicolumn{2}{|l|}{ Polytropic index } \\
\hline$A c$ & Area of the collector & $\mathrm{m}^{2}$ & & Pressure ratio & bar \\
\hline $\mathrm{C}_{\pi}$ & Specific heat of water, refrigerant & $\mathrm{J} / \mathrm{kgK}$ & $\operatorname{Pr}$ & Prantal number & \\
\hline$D$ & Diameter of the copper tubes & $\mathrm{m}$ & $t_{m}$ & Mean evaporative temperature & ${ }^{\circ} \mathrm{C}$ \\
\hline$d$ & Plate thickness & $\mathrm{mm}$ & $t_{2}$ & Ambient temperature & ${ }^{\circ} \mathrm{C}$ \\
\hline$E$ & Correction factor & & $v_{w}$ & Wind speed & $\mathrm{m} / \mathrm{s}$ \\
\hline $\mathrm{I}$ & Solar irradiation & $\mathrm{W} / \mathrm{m}^{2}$ & v & Average velocity & $\mathrm{m} / \mathrm{s}$ \\
\hline $\mathrm{K}$ & Thermal conductivity, absorber plate & $\mathrm{W} / \mathrm{m}^{2} \mathrm{~K}$ & $v$ & Kinematic viscosity & $\mathrm{m}^{2} / \mathrm{s}$ \\
\hline $\mathrm{L}$ & Length of the copper tube & $\mathrm{m}$ & & & \\
\hline M & Molarmass & & $\alpha$ & absorvity & \\
\hline $\mathrm{m} t$ & Mass flow rate of refrigerant & $\mathrm{kg} / \mathrm{m}^{2}$ & $\epsilon$ & emissivity & \\
\hline $\mathrm{m}_{\mathrm{W}}$ & Mass flow rate of water & $\mathrm{kg} / \mathrm{m}^{2}$ & $\sigma$ & boltzman constant & \\
\hline $\mathrm{N}$ & Number of riser tubes & & $\Phi$ & latitude angle & \\
\hline
\end{tabular}

\section{II. $\quad \mathrm{CO}_{2}$ : PROMISING REFRIGERANT}

The refrigerant characteristics have a greater impact on the performance of DX-SAHP. Though there are many conventional refrigerants being used widely in this application such as R22, R134a, R12 or combination of refrigerants. $\mathrm{CO}_{2}$ (R744) is the natural refrigerant which imposes negligible effect on the environment. $\mathrm{CO}_{2}$ has a very low Ozone Depletion Potential (ODP) and Global Warming Potential (GWP) [1]. Carbon dioxide is colorless, odorless, naturally occurring gas. Carbon dioxide has played key role for sustainability of plants and human kind on this planet. Carbon dioxide has a very good thermo-physical and transport properties as compared to other refrigerants. The heat transfer properties of $\mathrm{CO}_{2}$ are favorable especially near to its critical point compared to other conventionally used working fluids. $\mathrm{CO}_{2}$ has a small change in saturation temperature for a given saturation paper and thus the efficiency of $\mathrm{CO}_{2}$ heat pump does not affect much with large change in pressure [2]. It is environmental friendly nonflammable, chemically inactive.

\section{NUMERICAL ANAL YSIS OF DIRECT EXPANSION SOLAR ASSISTED HEAT PUMP (DX-SAHP)}

The performance of direct expansion solar assisted heat pump water heating system with $\mathrm{CO}_{2}$ as refrigerant is analyzed theoretically with U-pipe evacuated tube solar collector as an evaporator of area $2 \mathrm{~m}^{2}$ and condenser tubes place inside the storage tank of 100L. Figure 1 shows the schematic view of the system considered for analysis.

The following assumptions were made for the theoretical analysis.

1. Steady state heat transfer process

2. Pressure drop in connecting pipes are negligible

3. Isenthalpic expansion is considered

4. The inlet water temperature is $30^{\circ} \mathrm{C}$ and the wind velocity of the ambient was being assumed as $5 \mathrm{~m} / \mathrm{s}$.

5. The collector is placed in a latitude angle of $13^{\circ}$

\section{MODELLING OF COLLECTOR/EVAPORATOR}

The energy gained by the collector/evaporator is given by [3]

$$
Q_{u}=A_{c L} F^{\prime}\left(S-U_{L}\left(t_{m}-t_{a}\right)\right)
$$

The value of $\mathrm{S}$ is the difference between the solar radiation absorbed by the collector/evaporator and the net radiation heat loss from the collector/evaporator surface at ambient temperature

$$
\mathrm{S}=\alpha \mathrm{I}_{\mathrm{T}}-\epsilon \mathrm{q}_{\mathrm{o}}
$$

The rate of heat transfer from the base of the fin to the tube is given by,

$$
\mathrm{F}=\frac{\tan \mathrm{h}\left(\sqrt{\frac{\mathrm{U}_{\mathrm{L}}}{\mathrm{kd}}} * \frac{\mathrm{W}-\mathrm{D}}{2}\right)}{\left(\sqrt{\frac{\mathrm{U}_{\mathrm{L}}}{\mathrm{kd}}} * \frac{\mathrm{W}-\mathrm{D}}{2}\right)}
$$

Where $\mathrm{W}$ is the width of spacing between the riser tubes

The overall heat transfer coefficient solar collector is given includes the wind heat transfer coefficient and the ambient temperature and is given by

$$
\mathrm{U}_{\mathrm{L}}=\mathrm{h}_{\mathrm{w}}+4 \in \sigma \mathrm{T}_{\mathrm{a}}{ }^{3}
$$




\section{HEAT TRANSFER COEFFICIENT OF $\mathrm{CO}_{2}$}

1. Two Phase Region

The two phase heat transfer is given by the sum of heat transfer coefficient in nucleate boiling $\left(\mathrm{h}_{\mathrm{NCB}}\right)$ and the heat transfer in liquid phase $\left(\mathrm{h}_{\mathrm{l}}\right)[4]$.

$$
\begin{aligned}
\mathrm{h}_{\mathrm{TP}} & =\mathrm{Sh}_{\mathrm{NCB}}+\mathrm{Eh}_{\mathrm{l}} \\
\mathrm{h}_{\mathrm{NCB}} & =55 \operatorname{Pred}^{.12}(-.4343 \ln \text { Pred })^{-.55} \mathrm{M}^{-.5} \mathrm{q}^{.67} \\
\mathrm{~h}_{\mathrm{l}} & =.023 \mathrm{Re}^{.8} \operatorname{Pr}^{4} \frac{\mathrm{k}}{\mathrm{D}}
\end{aligned}
$$

\section{Superheated Region}

The Nusselt number is calculated as

$$
\mathrm{Nu}=\frac{\frac{\mathrm{f}}{8}(\mathrm{Re}-1000) \operatorname{Pr}}{12.7 \sqrt{\frac{\mathrm{f}}{8}}\left(\operatorname{Pr}^{\frac{2}{3}}-1\right)+1.07}
$$

The friction factor is given

$$
\mathrm{f}=(.79 \ln (\mathrm{Re})-1.64)^{-2}
$$

Reynold's number

$$
\mathrm{Re}=\frac{\mathrm{uD}}{\mathrm{v}}
$$

\section{MODELLING OF COMPRESSOR}

The specific work of compressor is given by

$$
w=\frac{n}{n-1} P_{1} v_{1}\left(\left[\frac{P_{2}}{P_{1}}\right]^{\frac{n-1}{n}}-1\right)
$$

Where $P_{2}$ and $P_{1}$ are are the saturation pressure in condenser and evaporator . The compressor work can be obtained from the mass flow rate of the refrigerant $(\mathrm{m})$ as The compressor work $\mathrm{W}=\mathrm{m} * \mathrm{~W}$

\section{MODELLING THE CONDENSER}

In this case one turnover period, $\mathrm{t}_{\mathrm{T}}$ of stratified storage tank is very small and this can be easily achieved in a horizontal storage tank with high circulating $\mathrm{CO}_{2}$ flow rate, well mixed storage might seem to be inherently less efficient due to high temperature of the fluid leaving storage tank. This loss is compensated by the high heat transfer factor attainable with large flow of fluid through the collector.

$$
\mathrm{q}_{\mathrm{T}}=\frac{\mathrm{F}_{\mathrm{X}}\left[(\epsilon \alpha) \mathrm{I}_{\mathrm{T}}-\mathrm{U}_{\mathrm{L}}\left(\mathrm{T}_{\mathrm{S}}-\mathrm{T}_{\mathrm{a}}\right)\right] \mathrm{t}_{\mathrm{T}}}{1+\frac{\mathrm{F}_{\mathrm{K}} \mathrm{U}_{\mathrm{L}} \mathrm{t}_{\mathrm{T}}}{2 \mathrm{~m}_{\mathrm{S}} \mathrm{C}_{\mathrm{S}}}}
$$

\section{Heat Removal Factor}

The factor $F_{R}$ reduces the useful energy gain from the expected value is given by

$$
F_{R}=\left[\frac{m C_{f}}{A_{c}}\right]\left[1-\exp \left(-\frac{A_{c} U_{L} F^{\prime}}{m C_{f}}\right)\right]
$$

\section{Heat Exchanger Factor}

If $\mathrm{q}$ is the net heat flux collected per unit collector area, then the heat transferred through the heat exchanger to the water of insulated tank is $h=\Delta \mathrm{U}_{\mathrm{x}}$

$$
\mathrm{U}_{\mathrm{x}}=52.7\left[\frac{\mathrm{q}\left(\frac{\mathrm{Ac}}{\mathrm{Ax}}\right)}{\mathrm{Lo}}\right)^{\frac{1}{5}}
$$

Since the heat loss in the connecting pipe between the storage tank and heat exchanger is negligible and the equation is given by

$$
F_{x}=\left[1+\frac{F_{R} U_{L}}{m_{f} C_{f}}(\epsilon-1)\right]^{-1}
$$

Where $\mathrm{m}_{\mathrm{f}} \mathrm{C}_{\mathrm{f}}$ are the mass flow rate and specific heat of the refrigerant The effectiveness of the heat exchanger is

$$
\epsilon=1-\exp (-\mathrm{NTU})
$$




\section{Output Temperature}

The output temperature of the system represents by $\mathrm{T}_{\mathrm{so}}$,

$$
\mathrm{T}_{\mathrm{so}}=\mathrm{T}_{\mathrm{si}}+\frac{\mathrm{qT}_{\mathrm{T}}}{\mathrm{m}_{\mathrm{w}} \mathrm{C}_{\mathrm{w}}}
$$

Where $T_{s i}$ is the input water temperature and $\mathrm{m}_{\mathrm{w}} \mathrm{C}_{\mathrm{w}}$ are mass flow rate and specific heat of water in the water tank.

\section{Condenser Heat Gain}

The heat gained by condenser with temperature difference of the input and output water temperature of the storage tank/ condenser as following

$$
\mathrm{Q}_{\mathrm{c}}=\mathrm{m}_{\mathrm{w}} \mathrm{C}_{\mathrm{w}}\left(\mathrm{T}_{\mathrm{wo}}-\mathrm{T}_{\mathrm{wi}}\right)
$$

\section{SYSTEM PERFORMANCE}

The efficiency of the collector/evaporator is given by

$$
\eta=\frac{\text { net energy obsorbed by the collector }}{\text { solar energy on absorber of collector }}=\frac{Q_{u}}{A_{c} I}
$$

The COP of the heat pump system is expressed as

$$
\mathrm{COP}=\frac{\text { Heating Capacity }}{\text { Total Energy Input }}=\frac{\mathrm{Q}_{\mathrm{C}}}{\mathrm{W}}
$$

\section{RESULTS AND DISCUSSION}

The variation of COP and heat output with ambient temperature is shown in fig 2 . The COP of heat pump is greatly affected by the evaporator temperature which is influenced by solar intensity. The COP increases with increase in temperature. The speed of compressor is main factor in determining the COP of heat pump. Thus COP decreases with increase in speed of compressor and collector efficiency decreases. The heat output rejected to the storage tank is also influenced by the increase in ambient temperature.

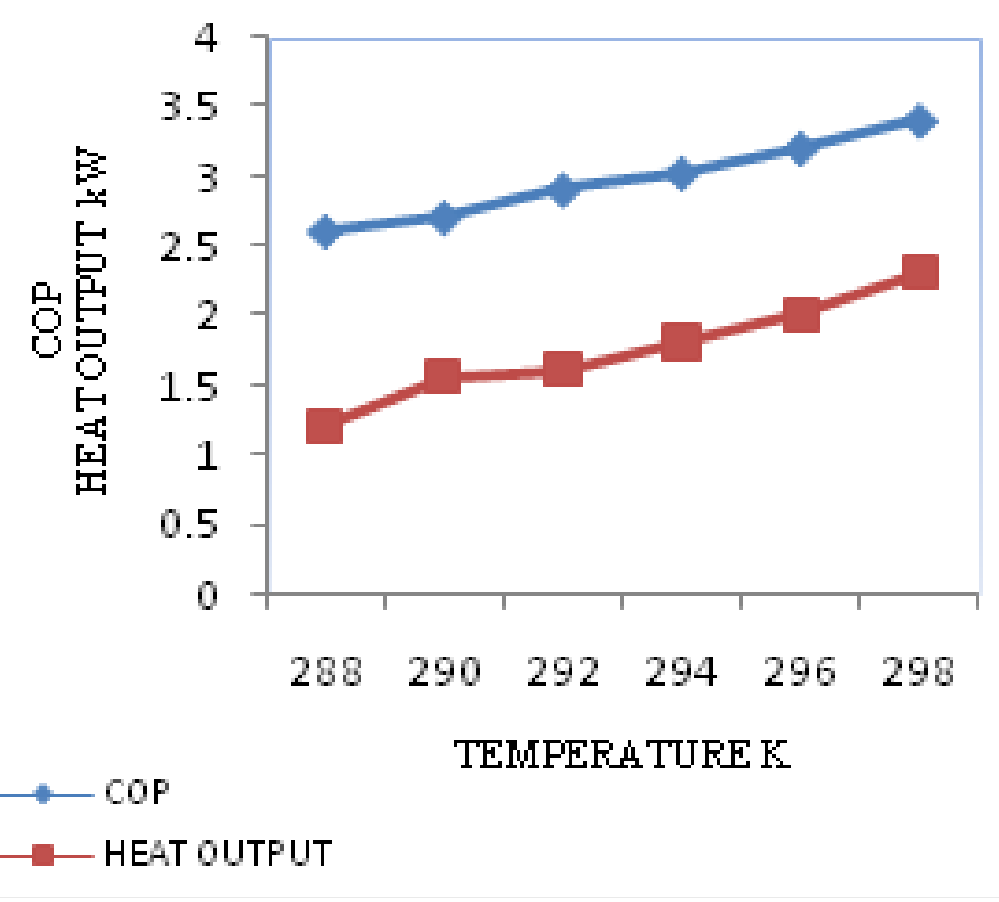

Fig 2 .COP and heat output Vs Ambient temperature 
TABLE 1. Comparison of parameters of water heaters

\begin{tabular}{|c|c|c|}
\hline PARAMETERS & $\begin{array}{l}\text { DX- SAHP } \\
\text { WATER } \\
\text { HEATER }\end{array}$ & $\begin{array}{c}\text { THERMOSYPHON } \\
\text { WATER } \\
\text { HEATER }\end{array}$ \\
\hline Heat transfer coefficient, $\mathrm{h}$ & $512 \mathrm{~W} / \mathrm{m}^{2} \mathrm{~K}$ & $213.77 \mathrm{~W} / \mathrm{m}^{2} \mathrm{~K}$ \\
\hline Collector efficiency, $\eta$ & 0.65 & 0.40 \\
\hline Heat removal factor, $F_{R}$ & 8.34 & 0.54 \\
\hline $\begin{array}{l}\text { Net rate of useful heat } \\
\text { energy per } m^{2}, Q_{u}\end{array}$ & $627.5 \mathrm{~W} / \mathrm{m}^{2}$ & $392.6 \mathrm{~W} / \mathrm{m}^{2}$ \\
\hline
\end{tabular}

The variation of collector efficiency with ambient temperature is shown in fig 3. The heat transfer coefficient of the $\mathrm{CO}_{2}$ is more in two phase region is more than the superheated region causing effective heat transfer in collector/evaporator region and increasing the collector/evaporator efficiency further. The collector efficiency increases with increase in the solar radiation intensity

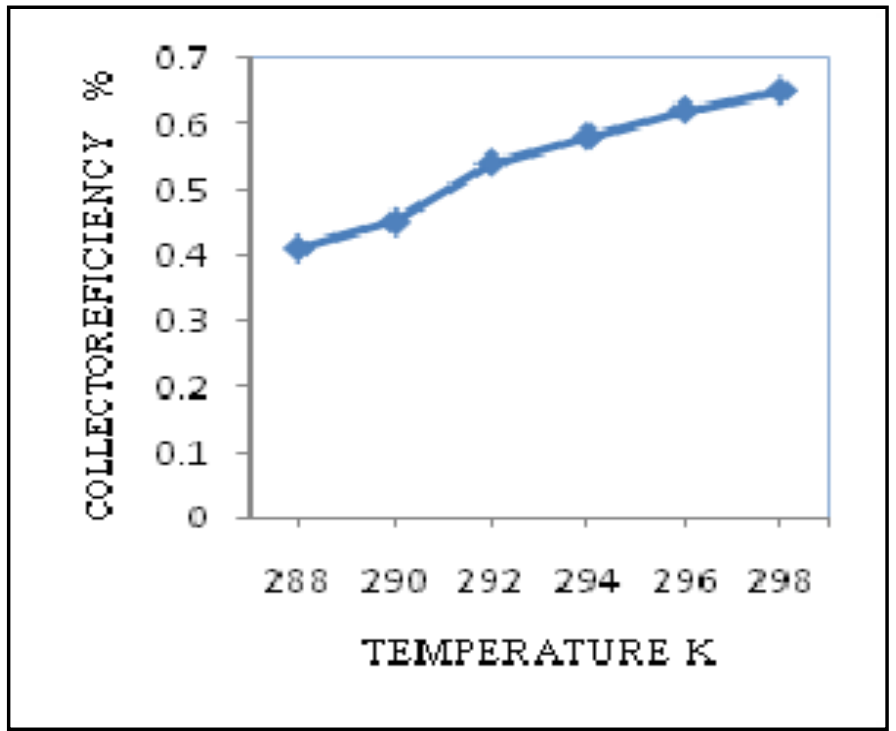

Fig 3. Collector efficiency Vs Ambient temperature

The specific work of compressor decreases with increase in solar radiation. This causes lower energy consumption. The variation of compressor speed increases the COP of the system which increases with increase in solar radiation. This is due to varying loading conditions with variation in solar intensity.

\section{$\mathrm{X}$ CONCLUSION}

The theoretical analysis of DX-SAHP water heater with $\mathrm{CO}_{2}$ as refrigerant is done. For ambient temperature of $25^{\circ} \mathrm{C}$ the collector efficiency of about 0.65 is obtained which is 0.05 higher than the collector efficiency obtained for conventional solar water heating system under same amient condition. The heat output ranges from $1.2-2.3 \mathrm{~kW}$ for $15-25^{\circ} \mathrm{C}$. The compressor work increases with increase in solar intensity. The COP of heat pump from $(3.2-4)$ is achieved. The performance of DX-SAHP water heater is evaluated theoretically and is found that the collector efficiency and output water temperature are high compared to conventional thermosyphon solar water heater under same conditions.

\section{REFERENCES}

[1] Kuang, Y.H., et al., “ Study on direct expansion solar assisted heat pump water heater” Int. J. Energ. Res., vol. 27, pp. 531-548, 2003

[2] Onder Ozgener and Arif Hepbasli "A review on the energy and exergy analysis of solar assisted heat pump systems" Renew. Sust. Energ. Rev., vol. 11, pp. 482-496, 2007

[3] Li,Y.W., et al., "Experimental performance analysis and optimization of direct expansion solar assisted heat pump water heater" Energy, vol. 32, pp. 1361-1374, 2007 
[4] Seok Ho Yoon, et al., " Characteristics of evaporative heat transfer and pressure drop of carbon dioxide and correlation development” Int. J. Refrig., vol. 27, pp. 111-119, 2004

[5] Srinivas.S.Pitla, et al., "New correlation to predict the heat transfer coefficient during in-tube cooling of turbulent supercritical CO2” Int. J. Refrig. , vol. 25, pp. 887-895, 2002

[6] Tiwari, G.N., "Solar energy, Fundamentals, design modeling and applications".

[7] Anderson, T.N. and Morrison, G.L. " Effect of load pattern on solar boosted heat pump water heater performance” Sol. Energy, vol. 81, pp.1386-1395, 2007

[8] Arif Hepbasli and Yildiz Kalinci "A review of heat pump water heating systems" Renew. Sust. Energ. Rev., 2008

[9] Axaopoulous, P., et al., "Experimental comparisons of solar assisted heat pump Vs conventional thermosyphon solar system” Int. J. Energ. Res., vol. 22, pp.1107-1120, 1998

[10] Aydin Dikici, Abdullah Akbulut "Performance characteristics and energy-exergy analysis of solar assisted heat pump system” Build. Environ., vol. 43, pp.1961-1972, 2008

[11] Aye. L, et al., "Solar heat pump system for domestic hot water" Sol. Energy vol. 73, pp. 169-175, 2002

[12] Xu Guoiying, et al., " A simulation study on operating performance of a solar air source heat pump water heater”, Appl. Therm. Eng., vol. 26, pp. 1257-1265, 2006

[13] $\mathrm{Xu}, \mathrm{G}$. et al., " A simulation study on the operating performance of solar air source heat pump water heater" Appl. Therm. Eng., vol. 26, pp. 1257-1265, 2006

[14] Huang, B.J. and Lee, C.P., " Performance evaluation method of solar assisted heat pump water heater" Appl. Therm. Eng., vol. 27, pp. 568-575, 2007

[15] Huang, B.J. et al., " Heat pipe enhanced solar assisted heat pump water heater” Sol. Energy, vol. 78, pp. 375-381, 2005

[16] Ito,S., et al.,“ Performance of heat pump using direct expansion solar collectors” Sol. Energy, vol. 65, pp. 189-196, 1999

[17] Ito,S., et al., "Studies of heat pump using direct expansion type solar collectors". J. Sol. Energ. Eng., vol. 127, pp. 33-44, 2003

[18] Yamaguchi, H., et al., “ A solar energy powered Rankine cycle using supercritical carbon dioxide” Appl. Therm. Eng., vol. 26, pp. 2345-2354, 2006

[19] Zhang, X.R. and Yamaguchi, H. " An experimental study on evacuated tube solar collector using supercritical CO2” Appl. Therm. Eng., vol. 28, pp. 1225-1233, 2008

[20] Zhang, X.R. et al., " Analysis of a novel solar energy powered Rankine cycle for combined heat and power application using supercritical carbon dioxide" Renew. Energ., vol 31, pp. 1839-1854, 2006 